\title{
IMPACT OF ADDING BIOPREPARATIONS ON THE ANAEROBIC CO-DIGESTION OF SEWAGE SLUDGE WITH GREASE TRAP WASTE
}

\author{
Małgorzata WORWĄG ${ }^{1}$ \\ Czestochowa University of Technology, Częstochowa, Poland
}

\begin{abstract}
The aim of the study was to evaluate the effect of using biopreparations on efficiency of the co-fermentation process. Commercial bacterial biopreparations DBC Plus Type L, DBC Plus Type R5 and yeast biopreparations were used in the study. The process of cofermentation of sewage sludge with grease trap waste from a production plant that manufactured methyl esters of fatty acids was analysed in the laboratory environment under mesophilic conditions. The sludge in the reactor was replaced once a day, with hydraulic retention time of 10 days. Grease trap waste accounted for $35 \%$ wt. of the fermentation mixture. The stabilization process was monitored everyday based on the measurements of biogas volume. Addition of yeast biopreparation to methane fermentation of sewage sludge with grease trap waste caused an increase in mean daily biogas production from $6.9 \mathrm{dm}^{3}$ (control mixture) to $9.21 \mathrm{dm}^{3}$ (mixture $\mathrm{M} 3$ ). No differences in biogas production were found for other cases (mixtures M1, M2). A similar relationship was observed for methane content in biogas.
\end{abstract}

Keywords: biopreparations, co-fermentation, grease trap waste, biogas

\section{INTRODUCTION}

From the standpoint of energy recovery, anaerobic digestion is one of the most promising treatments for municipal sludge [1]. Furthermore, it is also the most

\footnotetext{
${ }^{1}$ Corresponding author: Czestochowa University of Technology, Faculty of Infrastructure and Environment, Institute of Environmental Engineering,Brzeźnicka st. 60A, 42 -200 Częstochowa, Poland, e-mail: mworwag@ is.pcz.czest.pl
} 
frequent treatment technology in large and medium-sized wastewater treatment plants (WWTP) [2]. Grease trap waste (GTW) is understood to mean solid waste (scum layer) obtained from the flotation process in a WWTP, which is composed by several types of oil and fat. GTW is typically collected and disposed in landfills. However, this waste must be stabilized prior to the disposal due to strict regulations and the problems associated with this type of waste (such as foul odors). Anaerobic digestion might be used in order to degrade and stabilize GTW along with sewage sludge (SS). An important advantage of this method is that the same facilities can be used for sewage sludge degradation, without additional investment costs. Furthermore, due to its high lipidcontent, GTW represents an attractive source for biomethanization due to the higher methane yield compared to proteins or carbohydrates $[3,4]$. Anaerobic co-digestion is a process where several wastes are used as substrates, for instance, SS and lipid-rich waste [5]. Luostarinen et al. [6] found that the codigestion of SS and GTW (from meat industry) improved the biogas production and methane yield at low and high GTW concentrations. Davidsson et al. [7] evaluated the anaerobic digestion of these wastes in batch and continuous pilotscale digestion tests and found that the addition of GTW increased methane yield and methane potential in batch tests. Hydrolysis is recognized as a ratelimiting step in the complex digestion process. Therefore, pretreatment is necessary to make organic matter bioavailable to the microorganisms during digestion [2]. Biological pretreatment offers unique advantages compared to chemical or physical processes as it is environmental friendly and neither causes pollution nor needs special equipment [8]. Biological pretreatment is aimed at intensification by enhancing the hydrolysis process in an additional stage prior to the main digestion process [2]. Biological pretreatment can be classified into 2 categories: (1) adding industrial [9] or endogenous enzymes prior to anaerobic digestion processes; (2) adding specific bacteria which can release certain enzymes $[10,11]$. They have been shown to improve degradation, dewatering properties of the sludge and to increase methane production, and have been widely researched in laboratory and full-scale plants [12].

The use of biopreparations can improve anaerobic degradation of lipids and act as a catalyst for hydrolysis of long chain fatty acids. Biopreparations are biodegradable and harmless to the anaerobic treatment processes and aquatic ecosystems; in addition, their contribution to the BOD in the waste stream is negligible. Biopreparations and enzymes have been used in anaerobic treatment of fat-wastewater [13-15]. However, there is a lack of literature regarding the use of biopreparations for anaerobic co-degradation of solid-lipid waste such as GTW and SS. Pretreatment of mixed sludge with enzymes prior to the anaerobic digestion was shown to improve the degradation of the sludge and led 
to enhanced methane production [16-19]. The previous studies suggest that the addition of exogenous microorganisms can improve the performance of anaerobic digestion systems. However, microorganisms' activity can be affected by many factors including the substrate, incubation time, system configuration, and environmental conditions (e.g. temperature and $\mathrm{pH}$ ). More research is needed to determine if and when the addition of microrganisms to the anaerobic digestion system will improve digestion rates and biogas yields.

The aim of this study is to determine the influence of addition of various biopreparations to co-fermentation methane sewage sludge of fatty wastes.

\section{METHODOLOGY}

\subsection{Materials}

Substrates were sewage sludge (SS) from municipal wastewater treatment plant (Silesian Region, Poland) (sediments were collected from the pipeline that supplied mixed sludge to the digester) and fatty waste from a plant that manufactured methyl esters of fatty acids (GTW).

The dry matter content of organic matter in sewage sludge was about $69 \%$, whereas for the mixture of sludge from fatty waste, this value was about $72 \%$. The concentration of VFA was $2411.43 \mathrm{mg} \mathrm{CH} \mathrm{CHOOH}_{3} \mathrm{dm}$ for sewage sludge and $2537.14 \mathrm{mg} \mathrm{CH} \mathrm{CH}_{3} \mathrm{COOH} / \mathrm{dm}^{3}$ for the mixture. Characteristics of the the substrates are presented in Table 1.

Biopreparations used in the study: DBC Plus Type L, Type R5 DBC Plus, yeast nutrients. DBC Plus cultures are a blend of harmless saprophytic bacterial strains originally isolated from the natural environment which utilize nonliving organic matter as a food source. The bacteria are selected microorganisms, carefully chosen for their capability of biodegradation to harmless end products. Being saprophytic, they are not pathogenic, toxic, caustic or corrosive and therefore are safe to use, having no harmful side effects. The cultures are harmless to both aquatic and land plants and animals, and have been released into marine, fresh water and soil treatment areas with complete ecological safety. DBC Plus Type L is a powder enhanced with surfactants, buffer and enzymatic substances that accelerate removal of fatty deposits. DBC Plus Type R-5 culture have been widely used in heavier petroleum products e.g. diesel fuel. Biopreparations contain air dried and lyophilised bacteria of the genus: Bacillus sp., Arthrobacter sp., Acinetobacter sp., Pseudomonas sp., Enterobacter sp. [20]. 
Table 1. Characteristics of substrate

\begin{tabular}{|c|c|c|c|}
\hline Index & SS & Mixture & GTW \\
\hline Dry matter $\left[\mathrm{g} / \mathrm{dm}^{3}\right]$ & $26.45 \pm 0.89$ & $41.09 \pm 1,07$ & 431.52 \\
\hline Dry organic matter $\left[\mathrm{g} / \mathrm{dm}^{3}\right]$ & $18.13 \pm 0.55$ & $29.43 \pm 0.65$ & 281.87 \\
\hline Dry mineral matter $\left[\mathrm{g} / \mathrm{dm}^{3}\right]$ & $8.32 \pm 0.45$ & $11.66 \pm 0.43$ & 149.65 \\
\hline VFA $\left[\mathrm{mg} \mathrm{CH}_{3} \mathrm{COOH} / \mathrm{dm}^{3}\right]$ & $2411.43 \pm 110.21$ & $2537.14 \pm 34.29$ & - \\
\hline $\begin{array}{c}\text { Ammonium nitrogen } \\
{\left[\mathrm{mg} \mathrm{N}_{\mathrm{NH}} / \mathrm{dm}^{3}\right]}\end{array}$ & $218.4 \pm 9.7$ & $231.47 \pm 6.47$ & - \\
\hline $\mathrm{pH}$ & $6.22 \pm 0,02$ & $4.97 \pm 0.06$ & - \\
\hline Alkalinity $\left[\mathrm{mg} \mathrm{CaCO}_{3 /} \mathrm{dm}^{3}\right]$ & $1406.67 \pm 956.43$ & $993.33 \pm 703.64$ & - \\
\hline $\mathrm{COD}\left[\mathrm{mg} \mathrm{O}_{2} / \mathrm{dm}^{3}\right]$ & $1689 \pm 646$ & $1341 \pm 68.04$ & - \\
\hline
\end{tabular}

Table 2 shows contents of each substrate in the co-fermentation mixture. All the mixtures had similar weight concentrations of individual components. The mixture Mk was a control mixture. Biopreparations DBC plus L-type and DBC plus $\mathrm{R} 5$ with the volume of $30 \mathrm{ml} / \mathrm{d}$ were added to the mixtures 1 and 2 , whereas yeast bioperation was added only once to the mixture 3, with $20 \mathrm{~g}$ of yeast dissolved in $350 \mathrm{ml}$ of water. All biopreparations had been prepared one day before they were introduced to the bioreactor.

Table 2. Part of substrates in the mixture for co-fermetation

\begin{tabular}{c|c|c|c}
\hline Mixture & SS & GTW & Biopreparation \\
\cline { 1 - 1 } Mc & & & - \\
\cline { 1 - 1 } M1 & \multirow{3}{*}{$65 \%$} & $35 \%$ & DBC Plus type L $(30 \mathrm{ml} / \mathrm{d})$ \\
\cline { 1 - 1 } M2 & d.m.o. & d.m.o. & DBC Plus type $\mathrm{R} 5(30 \mathrm{ml} / \mathrm{d})$ \\
\cline { 1 - 1 } M3 & & & yeast nutrients $(20 \mathrm{~g} / 350 \mathrm{ml})$ \\
\hline
\end{tabular}

\subsection{Sample analysis}

Total solids (TS), volatile solids (VS), $\mathrm{pH}$, alkalinity, total volatile acids (VFAs) and ammoniacal nitrogen (steam distillation - BÜCHI K-355) were determined according to APHA (1995) standard methods. Biogas production was measured each day using the water displacement method, whereas the methane percent in biogas was analyzed in a portable gas analyzer (NANOSENS). All gas results were calculated for standard temperature and pressure. The results of physical and chemical analysis will be used to determine the effect of biopreparations on the course and effectiveness of 
methane fermentation expressed as a degree of organic matter removal and specific methane yield.

\subsection{Experimental procedure}

Digestion was carried out using a 6.51 glass reactor at $37^{\circ} \mathrm{C}$ (Figure 1). The reactor was operated in draw-and-fill mode with retention time of 10 days. The mixture in the reactor was changed every 24 hours. Daily biogas composition and volume were analysed and recorded. Analysis of other indices for the mixture released from the bioreactor was performed every 5 days. The reactor is equipped in a system that maintains constant processing temperature, apparatus for adequate mixing and an installation for biogas capture (leveling cylinder and the cylinder filled with a saturated solution of sodium chloride). The digester was equipped in a water jacket for heating the sludge filling chamber. In the first part of the experiment, the reactor was fed with a mixture of sewage sludge and grease trap sludge. This paper presents the data obtained during codigestion of sludge with grease trap waste addition of $35 \%$ per volatile solids (VS). Next, bioperapartions were added to the mixture. Fig. 2 presents the study design showing the duration of each step.

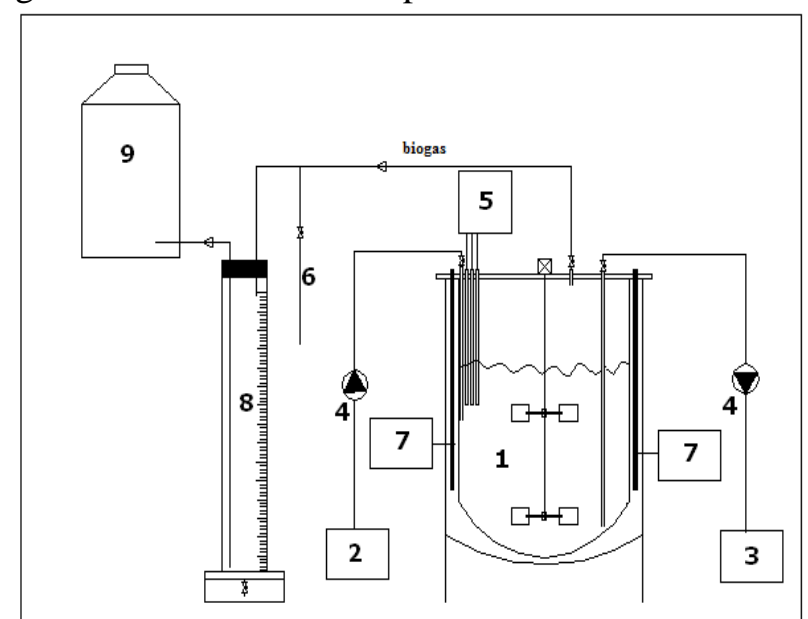

Fig. 1. Digester set-up: (1) reactor, (2) influent, (3) effluent, (4) pump, (5) pH, redox meter, $(8,9)$ gas meter [3]

\section{RESULTS AND DISCUSSION}

The results of the physico-chemical co-fermentation in a fed-batch bioreactor discharged from the fermentate are shown in Table 3. Dry mineral matter, dry 
organic matter and the dry weight of mineral during the process remained steady, but addition of biopreparations 2 and 3 led to the increase in these values by approximately 20\%. Dry organic matter in the fermentate was reduced by about $65 \%$ compared to the mixture fed (Tab. 1). The VFA concentration for the mixture added to the reactor was $2537.14 \mathrm{mg} / \mathrm{dm}^{3}$, whereas this value for the mixture discharged from the reactor decreased to 937.14 to $457.14 \mathrm{mg} / \mathrm{dm}^{3}$ for the mixture control. In the case of mixtures 1 and 2 , the parameter studied remained at a similar level.

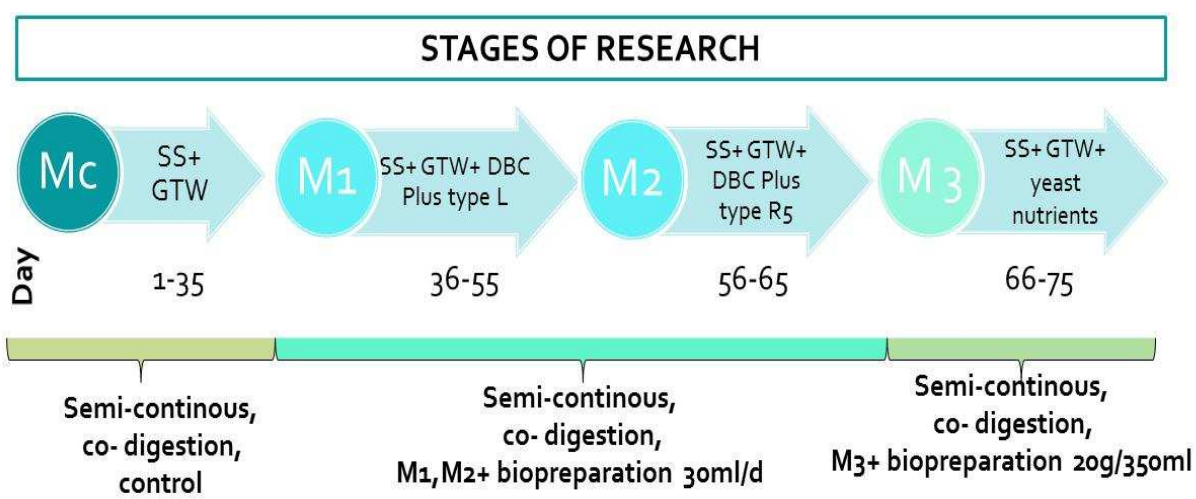

Fig. 2. Research schedule

The highest concentration of VFA $1897.14 \mathrm{mg} / \mathrm{dm}^{3}$ was observed for the mixture 3, which could have been attributed to the introduction of the biopreparation. The alkalinity remained at a similar level during the process but it increased by about $20 \%$ at the end of the process after adding the yeast biopreparation. The $\mathrm{pH}$ was generally not altered during the process, ranging from 7.26 to 7.96. The concentration of ammonia nitrogen remained steady, but it increased by about $34 \%$ after addition of biopreparation yeast nutrients.

Table 4. Biogas

\begin{tabular}{|c|c|c|c|}
\hline Day & Biogas $\mathrm{dm}^{3} / \mathrm{d}$ & Methane $\mathrm{dm}^{3} / \mathrm{d}$ & Methane \% \\
\hline Mc $(1-35)$ & $6.90 \pm 0.48$ & $4.97 \pm 0.34$ & $72.04 \pm 1.01$ \\
\hline M1 (36 - 55) & $5.88 \pm 1.40$ & $4.23 \pm 0.99$ & $72.13 \pm 0.65$ \\
\hline M2 (56 - 65) & $6.95 \pm 0.19$ & $5.08 \pm 0.16$ & $73.08 \pm 0.75$ \\
\hline M3 (66 - 75) & $9.21 \pm 1.55$ & $6.41 \pm 1.08$ & $69.79 \pm 3.82$ \\
\hline
\end{tabular}


Table 3. Results of physicochemical measurements

\begin{tabular}{|c|c|c|c|c|c|c|c|c|c|c|c|c|c|c|c|c|}
\hline & 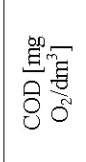 & 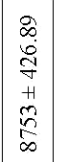 & $\begin{array}{l}\text { 年 } \\
\text { o } \\
\text { th } \\
\text { t } \\
\text { f } \\
\text { in }\end{array}$ & 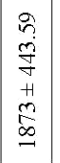 & $\begin{array}{l}n \\
\vdots \\
0 \\
+1 \\
0 \\
\vdots \\
\end{array}$ & 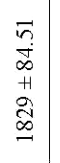 & $\begin{array}{l}\infty \\
0 \\
w \\
i \\
+ \\
0 \\
0 \\
0\end{array}$ & 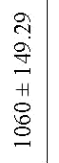 & 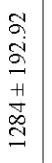 & $\begin{array}{l}\tilde{D} \\
\tilde{D} \\
\infty \\
+ \\
0 \\
0 \\
0\end{array}$ & 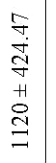 & 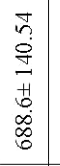 & $\begin{array}{l}3 \\
m \\
m \\
+ \\
\infty \\
\dot{B} \\
\vec{b}\end{array}$ & 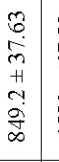 & 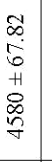 & 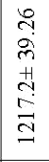 \\
\hline & 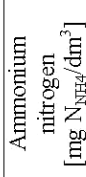 & & 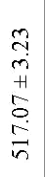 & $\mid \begin{array}{l}n \\
2 \\
\infty \\
+1 \\
m \\
2 \\
\dot{2} \\
\sigma\end{array}$ & 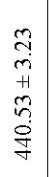 & $\begin{array}{l}0 \\
0 \\
0 \\
+ \\
0 \\
o \\
\dot{q}\end{array}$ & 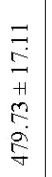 & 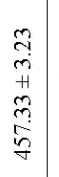 & 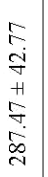 & $\begin{array}{l}0 \\
0 \\
\dot{y} \\
+ \\
\tilde{N} \\
\tilde{\sigma} \\
\dot{\sigma}\end{array}$ & $\begin{array}{l}\stackrel{y}{=} \\
\frac{H}{J} \\
\frac{F}{F}\end{array}$ & 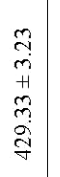 & 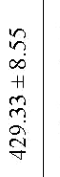 & 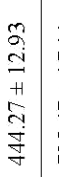 & & 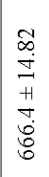 \\
\hline & 营 & $\begin{array}{l}\overrightarrow{0} \\
0 \\
+ \\
+ \\
\infty \\
\sim\end{array}$ & 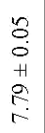 & 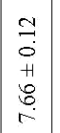 & 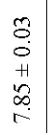 & 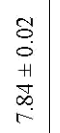 & $\begin{array}{l}0 \\
0 \\
0 \\
+ \\
0 \\
\vdots \\
r\end{array}$ & $\begin{array}{l}0 \\
0 \\
0 \\
+1 \\
+\infty \\
\stackrel{\alpha}{r}\end{array}$ & 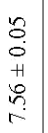 & 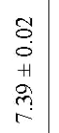 & $\begin{array}{l}\vec{\sigma} \\
0 \\
+ \\
n \\
n\end{array}$ & 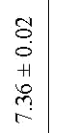 & 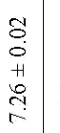 & 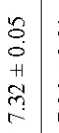 & 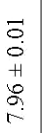 & 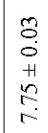 \\
\hline & 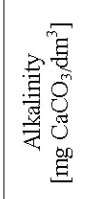 & 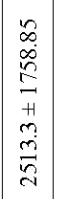 & 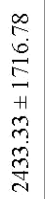 & 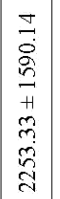 & 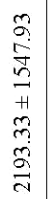 & 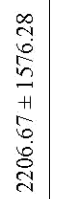 & 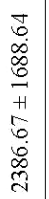 & 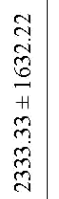 & 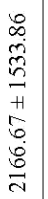 & 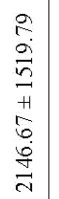 & 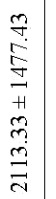 & 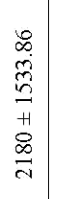 & 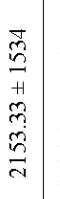 & 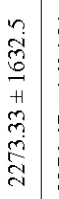 & 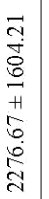 & 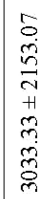 \\
\hline & 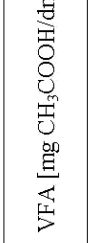 & 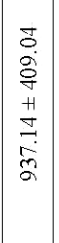 & 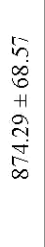 & 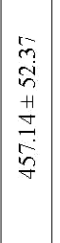 & 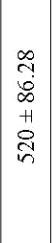 & 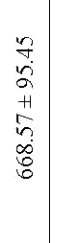 & 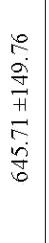 & 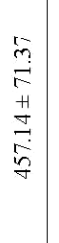 & 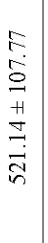 & $\mid$\begin{tabular}{c|c}
$\infty$ \\
$\infty$ \\
$\infty$ \\
$\infty$ \\
+1 \\
$n$ \\
$\infty$ \\
$\tilde{o}$ \\
0 \\
0
\end{tabular} & 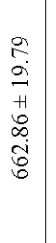 & 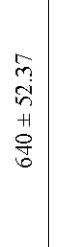 & 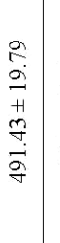 & 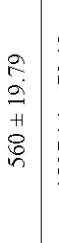 & & 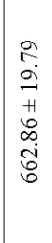 \\
\hline & & $\begin{array}{l}0 \\
0 \\
0 \\
+ \\
0 \\
= \\
=\end{array}$ & 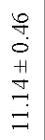 & $\begin{array}{l}\vec{c} \\
0 \\
+ \\
\infty \\
\stackrel{\infty}{\exists} \\
\exists\end{array}$ & $\begin{array}{l}\hat{m} \\
0 \\
+ \\
\infty \\
0 \\
\stackrel{0}{0}\end{array}$ & 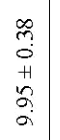 & $\begin{array}{l}0 \\
0 \\
0 \\
+ \\
2 \\
2 \\
2\end{array}$ & $\begin{array}{l}\vec{J} \\
0 \\
+ \\
+ \\
g \\
\exists\end{array}$ & $\begin{array}{l}0 \\
0 \\
0 \\
0 \\
\vdots \\
0 \\
\dot{0} \\
\dot{0}\end{array}$ & 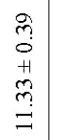 & $\begin{array}{l}n \\
0 \\
y \\
n \\
=\end{array}$ & $\begin{array}{l}2 \\
0 \\
+ \\
+1 \\
g \\
=\end{array}$ & $\begin{array}{l}\vec{a} \\
0 \\
\vec{H} \\
\vec{g} \\
\vec{I}\end{array}$ & 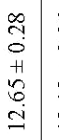 & & $\begin{array}{l}\tilde{I} \\
0 \\
+ \\
\dot{0} \\
\stackrel{j}{g}\end{array}$ \\
\hline & & 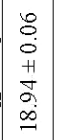 & 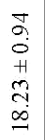 & 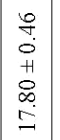 & 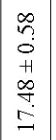 & $\begin{array}{l}\mathbf{r} \\
0 \\
0 \\
+1 \\
0 \\
0 \\
-1\end{array}$ & 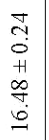 & $\begin{array}{l}0 \\
0 \\
0 \\
+1 \\
+ \\
\infty \\
\underline{D}\end{array}$ & 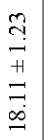 & $\begin{array}{l}\underset{\infty}{\infty} \\
0 \\
+ \\
\stackrel{+}{0} \\
\stackrel{\infty}{\infty}\end{array}$ & $\begin{array}{l}\bar{a} \\
0 \\
+1 \\
\vec{n} \\
\underline{a}\end{array}$ & 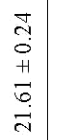 & $\begin{array}{l}\infty \\
0 \\
0 \\
+1 \\
\vec{i}\end{array}$ & 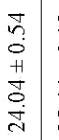 & & 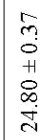 \\
\hline & 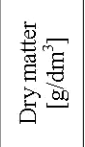 & \begin{tabular}{|l}
0 \\
0 \\
0 \\
+1 \\
$\infty$ \\
$\infty$ \\
0 \\
0
\end{tabular} & 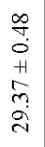 & 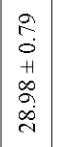 & 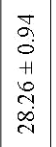 & 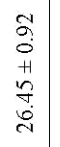 & $\begin{array}{l}0 \\
\vec{z} \\
0 \\
+ \\
0 \\
\dot{0} \\
\dot{c}\end{array}$ & $\begin{array}{l}0 \\
0 \\
0 \\
+1 \\
\infty \\
\vec{j} \\
\vec{j}\end{array}$ & 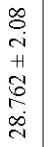 & $\begin{array}{l}0 \\
\infty \\
0 \\
+1 \\
0 \\
0 \\
a \\
\end{array}$ & $\begin{array}{l}\infty \\
0 \\
0 \\
\text { ते } \\
\text { m }\end{array}$ & 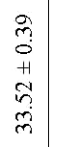 & $\begin{array}{c}m \\
\vdots \\
+ \\
m \\
n \\
n \\
m\end{array}$ & $\begin{array}{l}\vec{\infty} \\
\dot{0} \\
+ \\
\overrightarrow{0} \\
\dot{0} \\
\dot{m}\end{array}$ & & $\begin{array}{l}\stackrel{0}{0} \\
\dot{+} \\
\dot{\omega} \\
\infty \\
m\end{array}$ \\
\hline & 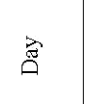 & & & & & & & & & & & & & & & \\
\hline
\end{tabular}


The level of biogas production during the process remained at a similar level. The Table 4 contains data on biogas content over the experiment. Biogass production decreased between the 36th and 55th day of the experiment. Adding biopreparations 1 and 2 had no effect on increasing the biogas production. However, addition of biopreparation 3 was followed by an increase in biogas production (Figure 5). The results show that methane content also decreased by approximately $5 \%$ after addition of yeast bioperaparation.

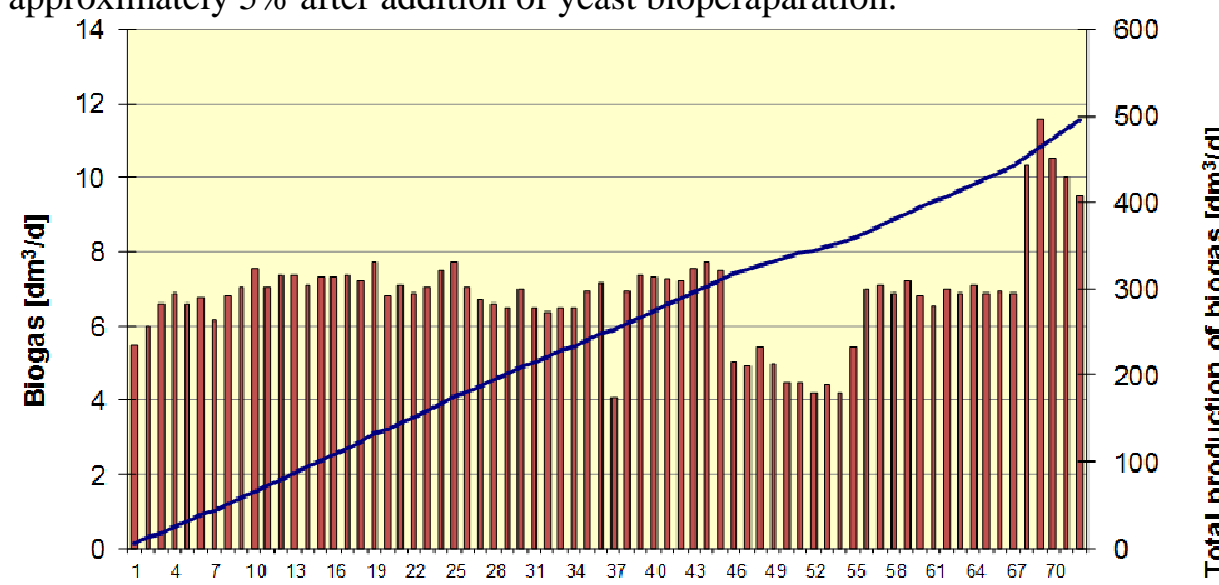

Time [d]

daily production of biogas $\quad$ total production of biogas

Fig. 5. The daily and total production of biogas

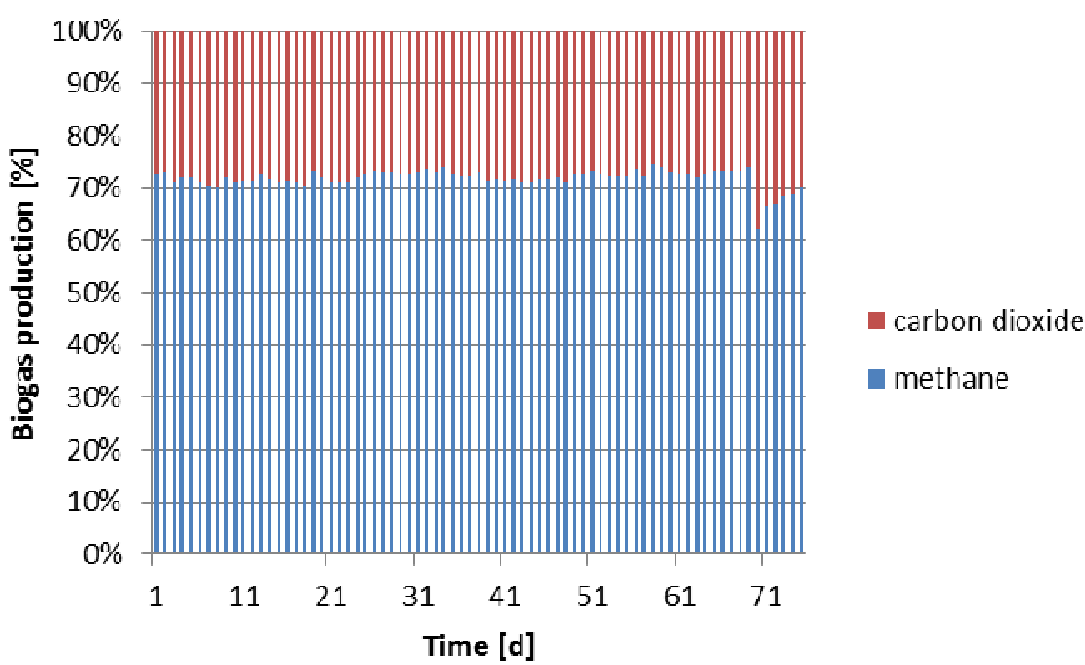

Fig. 6. The participation methane and carbon dioxide in the produced biogas 
As shown in Fig. 6, addition of biopreparations DBC Plus Type L and DBC Plus Type R5 did not affect the composition of biogas. Introduction of biopreparation yeast nutrients caused a decrease in methane content of about $70 \%$ to $62 \%$. Little research has been done on the additive biologicals and their influence on the process of anaerobic digestion of sewage sludge. However, much evidence has been presented concerning the beneficial effects of enzymes added over the methane fermentation process, showing that they are likely to shorten the process time [19] and reduce costs [21] and can be easily controlled. Furthermore, its products are innocuous to the environment [22].

\section{CONCLUSIONS}

This study evaluated biopreparations used to intensify co-digestion of sewage sludge with fatty waste. The results obtained during the tests lead to the following conclusions:

- The addition of biopreparations DBC plus the L and R 5 did not improve the efficiency of co-fermentation expressed in biogas production. Average daily production of biogas was $6.9 \mathrm{dm}^{3}, 5.88 \mathrm{dm}^{3}$ and $6.95 \mathrm{dm}^{3}$ for Mc, M1 and M2, respectively. The increase in average daily biogas production was observed only after addition of the yeast bioperapartion M3 $\left(9.21 \mathrm{dm}^{3}\right)$.

- The methane content in the control mixture, mixture 1 and mixture 2 was at a similar level of around $72 \%$. This level decreased for the mixture 3 to around $60 \%$, and, after several days, it rose again to around $70 \%$.

- Compared to the daily introduction of biopreparation (M1, M2), its onetime application (M3) helped improve the efficiency of biogas production, suggesting the need for further research on the frequency of the use of biopreparation, which should focus on the biopreparations 1 and 2.

\section{The source of finance: BS - PB - 401/301/11}

\section{REFERENCES}

1. Du Bois, E., Mercier, A., Energy recovery. In: Xu, C.C., Lancaster, J. (Eds.), Treatment of Secondary Sludge for Energy Recovery. Nova Science Publishers Inc., New York, 2009, 187-212.

2. Carrere H., Dumas C., Battimelli A., Batstone D.J., Delgenes J.P., Steyer J.P., Ferrer I.,. Pretreatment methods to improve sludge anaerobic degradability: a review. Journal of Hazardous Materials. Vol. 183, Issues 13, 2010, pp. 1-15. 
3. Grosser A., Worwag M., Neczaj E., Grobelak A., Semi-continous anaerobic co-digestion of mixed sewage sludge and waste fats of vegetable origin. Annual Set The Environment Protection, Vol.15 T.15 Part 3, 2013, s.21082125.

4. Neczaj E., Grosser A., Worwag M., Boosting Production of Methane from Sewage Sludge by Addition of Grease Trap Sludge. Environment Protection Engineering, Vol.39, nr 2, 2013, p.125-133.

5. Long JH, Aziz TN, de los Reyes III FL, Ducoste JJ. Anaerobic co-digestion of fat, oil, and grease (FOG): a review of gas production and process limitations. Process Saf Environ Protect 2012;90(3):231-45.

6. Luostarinen S, Luste S, Sillanpaa $M$. Increased biogas production at wastewater treatment plants through co-digestion of sewage sludge with grease trap sludge from a meat processing plant. Bioresour Technol 2009;100: 79-85.

7. Davidsson A, Lövstedt C, la Cour Jansen J, Gruvberger C, Aspegren H. Codigestion of grease trap sludge and sewage sludge. Waste Manage 28(6), 2008; 986-92.

8. Parawira, W., Enzyme research and applications in biotechnological intensification of biogas production. Crit. Rev. Biotechnol. 32, 2012;172186.

9. Yang, Q. et al., Enhanced efficiency of biological excess sludge hydrolysis under anaerobic digestion by additional enzymes. Bioresour. Technol. 101, 2010; 2924-2930.

10. Li, X.S., Ma, H.Z., Wang, Q.H., Matsumoto, S., Maeda, T., Ogawa, H.I., Isolation, identification of sludge-lysing strain and its utilization in thermophilic aerobic digestion for waste activated sludge. Bioresour. Technol. 100, 2009; 2475-2481.

11. Tang, Y., Yang, Y.L., Li, X.M., Yang, Q., Wang, D.B., Zeng, G.M., The isolation, identification of sludge-lysing thermophilic bacteria and its utilization in solubilization for excess sludge. Environ. Technol. 33, 2015; 961-966.

12. Parmar, N., Singh, A., Ward, O.P., Enzyme treatment to reduce solids and improve settling of sewage sludge. J. Ind. Microbiol. Biotechnol. 26, 2001; 383-386.

13. Valladao ABG, Sartore PE, Freire DMG, Cammarota MC. Evaluation of different pre-hydrolysis times and enzyme pool concentrations on the biodegradability of poultry slaughterhouse wastewater with a high fat content. Water Sci Technol 2009;60(1):243-9.

14. Rosa DR, Duarte ICS, Saavedra NK, Varesche MB, Zaiat M, Cammarota $\mathrm{MC}$, et al. Performance and molecular evaluation of an anaerobic system 
with suspended biomass for treating wastewater with high fat content after enzymatic hydrolysis. Bioresour Technol 2009;100(24):6170-6.

15. Mobarak-Qamsari E, Kasra-Kermanshahi R, Nosrati M, Amani T. Enzymatic prehydrolysis of high fat content dairy wastewater as a pretreatment for anaerobic digestion. Int J Environ Res 2012;6(2):475-80.

16. la Cour Jansen, J., Davidsson, A., Dey, E.S., Norrlow, O., Enzyme assisted sludge minimization. Chemical Water and Wastewater Treatment VIII, Gothenburg Symposium, Orlando, FL, United States, 2004; 345-353.

17. Lagerkvist, A., Chen, H., Control of two step anaerobic degradation of municipal solid waste (MSW) by enzyme addition. Water Sci. Technol. 27 (2), 1993; 47-56.

18. Wawrzynczyk, J., Dey, E.S., Norrlo“w, O., Jansen, J.l.C., Alternative method for sludge reduction using commercial enzymes. In: Eigth CIWEM/Aqua Enviro European Biosolids and Organic Residuals Conference, Wakefield, West Yorkshire, UK, 2003; 1-5.

19. Wawrzynczyk J., Recktenwald M., Norrlo O., Dey E.S., The function of cation-binding agents in the enzymatic treatment of municipal sludge, Watrer Research 42 (2008) 1555 - 1562.

20. www.bioarcus.pl, 20.01.2013

21. Ronja B., Enzymatic treatment of wastewater sludge in presence of a cation binding agent-improved solubilisation and increased methane production. Linkopings University, Sweden, 2008; 49-50.

22. Ahuja S.K., Ferreira G.M., Moreira A.R., Utilization of enzymes for environmental applications. Crit. Rev. Biotechnol. 24 (2-3), 2004; 125-154.

\section{WPŁYW STOSOWANIA BIOPREPARATÓW NA KOFERMENTACJĘ OSADÓW ŚCIEKOWYCH Z ODPADAMI TŁUSZCZOWYMI}

\section{Streszczenie}

Celem badań było określenie wpływu stosowania biopreparatów na efektywność procesu kofermentacji. W badaniach zastosowano biopreparaty komercyjne DBC Plus Typu L, DBC Plus Typu R5 (bakteryjne) oraz drożdże. Proces kofermentacji osadów ściekowych z odpadami tłuszczowymi pochodzącymi z wytwórni estrów metylowych kwasów tłuszczowych, przeprowadzono w skali laboratoryjnej w warunkach mezofilowych. Osady w reaktorze wymieniane były raz dziennie, przy hydraulicznym czasie zatrzymania 10 dni. Odpady tłuszczowe stanowiły 35\% wagowych mieszaniny fermentacyjnej. Kontroli prawidłowości przebiegu procesu stabilizacji dokonywano codziennie na podstawie pomiaru ilości produkowanego biogazu. Dodatek biopreparatu 
z drożdży do fermentacji metanowej osadów ściekowych z odpadami tłuszczowymi spowodował wzrost średnio dobowej produkcji biogazu z $6,9 \mathrm{dm}^{3}$ (dla kontroli) do $9.21 \mathrm{dm}^{3}$ (mieszanina M3). W pozostałych przypadkach (mieszaniny M1, M2) nie stwierdzono istotnych różnic w produkcji biogazy. Podobną zależność zaobserwowano dla zawartości metanu w biogazie.

Słowa kluczowe: biopreparaty, kofermentacja, odpady tłuszczowe, biogaz

Editor received the manuscript: 10.09 .2015 
